\title{
The Appraisal System in Greenpeace Food Campaigns
}

\author{
Maya Fitri Faoziah and Untung Yuwono* \\ Department of Linguistics, Faculty of Humanities, Universitas Indonesia, Depok 16424, Indonesia
}

\begin{abstract}
Since food is a necessity for human life, there have been many innovations aimed at speeding up food production. However, these innovations can have negative effects on the environment and, thus, the overall food system. Greenpeace, a non-governmental organization, creates food campaigns that include online materials touting a better food system, naming bad corporations, and asking readers or supporters to join the campaigns. This study analyzes Greenpeace's attitude in evaluating the environment using Halliday and Matthiessen's transitivity system and Martin and White's appraisal framework. The research was conducted using UAM CorpusTool software to perform a quantitative analysis of the data in terms of transitivity and appraisal. The results show that Greenpeace's food campaigns contain judgments as the most frequent appraisal in material clauses and relational clauses. These judgments concern how entities, processes, and innovations affect the environment.
\end{abstract}

Keywords: Appraisal, discourse, food campaign, Greenpeace, transitivity

ARTICLE INFO

Article history:

Received: 29 March 2019

Accepted: 6 April 2020

Published: 25 December 2020

DOI: https://doi.org/10.47836/pjssh.28.4.33

E-mail addresses:

maya.fitri@ui.ac.id (Maya Fitri Faoziah)

untung.yuwono@ui.ac.id (Untung Yuwono)

*Corresponding author

ISSN: 0128-7702

e-ISSN: 2231-8534

\section{INTRODUCTION}

Food is a necessity for sustaining human life, and our dependence on it has inspired various forms of food production, including genetics innovations and innovative food processing methods. However, innovations in food production do not always have positive impacts on human beings as they can have negative impacts on the environment, which in turn affect human life. 
In response to environmentally unfriendly food production, world organizations seek to improve food management and replace food systems that damage the Earth with ones that are environmentally friendly and sustainable. One of the world organizations campaigning on food is Greenpeace. This environmental organization spreads food campaign messages on its official website.

A campaign is usually triggered by human's activities which affect the environment (Scherrer, 2009). According to Trampe (2001), Greenpeace campaigns usually raise environment issues such as toxic materials, pollution, waste, destruction of natural habitats, extinction of species, and nuclear energy. The campaign slogan is Our Food, Our Future, which is inseparable from Greenpeace's evaluations of food management practices concerning their environmental conditions, character, and impact. They clearly state the enterprises and the industry that contribute in degrading environment. Therefore, they evaluate certain entity in their food campaign.

Greenpeace's campaigns also define the conservation which is important to preserve the environment. Therefore, the campaigns use some lexicons that relate to conservation. Yuniawan et al. (2019) stated the functions of those lexicons in the campaign were (1) an instrumental function to state a movement; (2) a representation function consisting of: (a) giving names, (b) describing characters, (c) describing activities (d) referring to places, (e) stating art diversity, (f) describing situations, (g) stating types; and (3) personal function to express compliments. Thus, the words or phrases in Greenpeace's campaign can express the act of Greenpeace whose aim is to be easily understood for the readers. Furthermore, the readers can implement the steps to protect environment.

The evaluation can be analyzed by appraisal. Appraisal plays an important role in ecolinguistics which includes ecology discourse since it can influence the mindset's of people about environment such as negative or positive evaluation (Stibbe, 2010). Moreover, the writers or the speakers can share their value by appraising (Hunston \& Thompson, 2000). Therefore, appraisal in ecology discourse can lead people to act and preserve for the environment by stating which things are good or bad for the environment.

The appraisal on the ecology discourse has been studied by Bednarek and Caple (2010). They applied the theory of appraisal of Martin and White (2005) to analyze the environmental reporting in the Australian newspaper, The Sydney Morning Herald. The study of Bednarek and Caple (2010) particularly found out the appraisal on image and the heading which only focused on appreciation and graduation aspect. Nurdiyani (2019) had also conducted a research of ecology discourse. She studied the appraisal of environmentalists relating to the issue of the capital move of Indonesia. She figured out that the environmentalists mostly criticized by expressing negative appreciation. However, another aspect of the appraisal is required to investigate the author's way to evaluate environment. 
Therefore, the purpose of this study was to examine how Greenpeace evaluates various entities in its food campaigns. We applied Martin and White's (2005) appraisal framework, which described the linguistic aspect in evaluating objects, things or phenomena as one part of language meta-function, namely, the interpersonal function. The framework also describes the subjectivity of the author of a text, seen how the author expresses his or her opinions and aligns them to the readers (Martin \& White, 2005). Particularly, by conducting this study, readers can recognise which are the good or bad side of food system for the environment. Furthermore, this research could expose the ideology of Greenpeace in the food campaign which was the evaluation might have influenced the readers' value. Hence, the readers are aware of bad food system such as agriculture, pesticides and large food factories.

\section{THEORETICAL REVIEW}

\section{Appraisal Framework}

Martin and White's (2005) appraisal framework identifies attitude, graduation, and engagement as the different domains of appraisal. Each is defined below.

Attitude describes how writers or speakers judge something, and it consists of three aspects, namely, affect, judgment, and appreciation (Martin \& White, 2005). Affect is concerned with emotions or feelings, including positive emotions like happiness and negative emotions like sadness (Martin \& White, 2005), which are respectively divided into un/happiness, in/security, and dis/satisfaction. Bednarek (2008) identified a new domain within affect, surprise, which according to Martin and White's (2005) appraisal framework is included in the negative feeling of insecurity. Bednarek (2008) considered that a new category was needed since suprise was not interpreted as negative meaning rather than neutral meaning.

A judgment is an evaluation shown by praising, criticizing, blaming, or admiring (Martin \& White, 2005). Judgment can be divided into five aspects, namely, normality, capacity, tenacity, veracity, and propriety (Martin \& White, 2005). Normality deals with usual and unusuality traits, such as whether something is natural, odd, lucky, or obscure. Capacity refers to capabilities, such as whether a person is powerful, weak, robust, sick, or successful. Tenacity deals with dependability, such as whether someone is un/reliable, un/dependable, or wary. Veracity deals with honesty, including traits such as truthfulness, lying, or dishonesty. Propriety deals with ethics, such as whether someone is im/moral, fair, or greedy.

Meanwhile, appreciation is divided into reaction, composition, and valuation. Reaction is concerned with the impact phenomena or things have on people's feelings, such as whether they are fascinating, boring, dull, or exciting. Composition is concerned with the balance or complexity of phenomena or things, while evaluation is concerned with the worth of phenomena or things, such as whether they are valuable, priceless, worthless, or useless. 
White (2015) clearly mentioned the assessment of positive and negative within appraisal's theory. The positive and negative of affect can be constructed by using the state of emotion such as happy is considered as positive and sad is considered as negative. While the positive and negative of judgement refer the behaviour of human which is in this study towards environment. The appreciation's dichotomy of positive and negative is based on the quality of phenomena or objects. In this case, the phenomena of food system which cause the destruction of environment is considered as negative appraisal. Yet, the act of preserving environment is positive.

Besides positive and negative, the appraisal can also be divided into inscribed and evoked. According to Oteíza (2017), inscribed appraisal means the evaluation is expressed directly whereas the evoked appraisal means the evaluation needs to be implied. the inscribed is usually realised by lexical items. on the other hand, evoked is expressed by metaphorical expression.

The graduation indicates the strength or weakness of an evaluation (Martin \& White, 2005). This domain is divided into force, which is the lexical realization of attitude, and focus, which is the lexical realization providing strong or weak effects of an appraisal. Force relates to intensity as shown through repetition; adverbs such as extremely, very, slightly, and greatly; and quantity as expressed by words like a few, nearby,small, large, and many. Meanwhile, focus relates to semantic categories that are not scalable, represented in expressions such as real, sort of, true, really, and kind of (Read \& Carroll, 2012). Hence, graduation clarifies and emphasizes the author's intention in a text.

Finally, engagement is an appraisal with two domains: how writers or speakers position themselves and how they position certain entities (Martin \& White, 2005).

Among these domains within the appraisal framework, this study focuses only on attitude and graduation.

\section{Transitivity}

Language reflects its social context (Halliday, 1985, in Haratyan, 2011). One function of language is to describe events or phenomena that can be represented by ideational clause (Halliday \& Matthiessen, 2014). Here, the transitivity system can elaborate clauses that represent an experience by describing the process, participants, and circumstances (Santoso, 2008). Transitivity involves at least two participants and an action that affects one participant (Hopper \& Thompson, 1980). Thus, transitivity includes in the domain of ideational metafunction explains what is happening and also the role and state in a clause. The transitivity analysis in this study identifies agents and their impacts on the environment by focusing on features such as processes, participants, and circumstances.

This study follows Halliday and Matthiessen's (2014) classification of process type. There are six processes: material, behavioral, mental, verbal, relational, and existential. The material process marks an action and something that 
is happening. Then, the behavioral process marks the behavior, while the mental process interprets things that are perceived by someone or something. The verbal process takes place in the spoken domain, the relational process relates to attributive and identifying while the existential process indicates that a particular entity exists. These process types are summarized in Table 1.

In this study, each process type corresponds to a clause type. Material clauses describe actions and environmental impacts. Meanwhile, relational clauses provide characteristics or attributes of entities mentioned in the food campaigns. Mental clauses mark that there are a set of considerations, reasoning, and emotions associated with food. Verbal clauses indicate the appraisal items that evaluate entities related to food. They present speech delivered by a particular entity about food or food systems. Existential clauses note the presence of the current food system. Thus, by identifying the participant, process, and circumstance, transitivity helps to construe experience of evaluating the environment (Mayo \& Taboada, 2017).

Table 1

Transitivity: process, meaning, and participants (Halliday \& Matthiessen, 2014)

\begin{tabular}{|c|c|c|c|}
\hline $\begin{array}{l}\text { PROCESS } \\
\text { TYPE }\end{array}$ & $\begin{array}{l}\text { Category } \\
\text { meaning }\end{array}$ & $\begin{array}{l}\text { Participants, } \\
\text { directly involved }\end{array}$ & $\begin{array}{l}\text { Participant, } \\
\text { Obliquely Involved }\end{array}$ \\
\hline $\begin{array}{l}\text { material: } \\
\qquad \begin{array}{r}\text { action } \\
\text { event }\end{array}\end{array}$ & $\begin{array}{l}\text { 'doing' } \\
\text { 'doing' } \\
\text { 'happening' }\end{array}$ & Actor, Goal & $\begin{array}{l}\text { Recipient, Client; } \\
\text { Scope; Initiator; } \\
\text { Attribute }\end{array}$ \\
\hline behavioural & 'behaving' & Behaver & Behaviour \\
\hline $\begin{array}{l}\text { Mental: } \\
\text { perception } \\
\text { cognition } \\
\text { desideration } \\
\text { emotion }\end{array}$ & $\begin{array}{l}\text { 'sensing' } \\
\text { 'seeing' } \\
\text { 'thinking' } \\
\text { 'wanting' } \\
\text { 'feeling' }\end{array}$ & $\begin{array}{l}\text { Senser, } \\
\text { Phenomenon }\end{array}$ & Inducer \\
\hline $\begin{array}{l}\text { Verbal } \\
\text { relational: } \\
\text { attribution } \\
\text { identification }\end{array}$ & $\begin{array}{l}\text { 'saying' } \\
\text { 'being' } \\
\text { 'attributing' } \\
\text { identifying }\end{array}$ & $\begin{array}{l}\text { Carrier, Attribute } \\
\text { Identified, } \\
\text { Identifier, Token, } \\
\text { Value }\end{array}$ & $\begin{array}{l}\text { Attributor; } \\
\text { Beneficiary, } \\
\text { Assigner }\end{array}$ \\
\hline Existential & 'existing' & Existent & \\
\hline
\end{tabular}




\section{METHOD}

\section{Data Collection}

The data in this study are the evaluation items contained in the food category of online text for Greenpeace campaigns. The data were taken from Greenpeace International's official website, https:// www.greenpeace.org/archive-international/ en/campaigns/agriculture/. There were 11 articles on the food category which were categorized into problem and solution. Only written data were collected, meaning that any food-related items mentioned in videos or visuals (and not also mentioned in the website text) were not analyzed.

The text of pages from Greenpeace's food campaigns was copied and transferred to Microsoft Word to facilitate the annotation step. Next, the data were annotated and categorized by appraisal domain such as affect, judgment, and appreciation. Whereas, the analysis of graduation is based on Martin and White's parameter of lexis.

\section{Data Analysis}

The study used corpus linguistics as an empirical method to analyze and describe the language data using statistical inference
(Crystal, 1992; Jackson, 2007, in Cheng, 2012). UAM CorpusTool was the software used for the systemic-functional analysis concerning transitivity and appraisal (O'Donnel1, 2014). That is, UAM CorpusTool was employed to identify the appraisal tendencies in Greenpeace food campaigns.

The analytical framework of the study was appraisal and transitivity, which is part of systemic-functional linguistics (Halliday \& Matthiessen, 2014). The first step was identifying the type of processes, participants, and circumstances in the clauses. The second step was describing the appraisals contained in the clauses. Then, in the third step, the appraisals were annotated based on the domains contained in the clauses (e.g., attitude and graduation), which show Greenpeace's attitude in evaluating the various entities.

\section{RESULTS AND DISCUSSION}

\section{Attitude in Clause Types}

The data show Greenpeace's attitudes and evaluation of various entities. Table 2 presents the frequency of each attitude type by the clause categories.

Table 2

Attitude by type of clause

\begin{tabular}{llll}
\hline Type of clause & Type of attitude & Number & $\%$ \\
\hline Material & affect & 1 & 0.85 \\
& judgment & 103 & 88.03 \\
& appreciation & 13 & 11.11 \\
\hline
\end{tabular}


Table 2 (Continued)

\begin{tabular}{llll}
\hline Type of clause & Type of attitude & Number & $\%$ \\
\hline Relational & affect & 13 & 11.30 \\
& judgment & 52 & 45.22 \\
Mental & appreciation & 50 & 43.48 \\
& affect & 1 & 5.88 \\
& judgment & 6 & 35.29 \\
Verbal & appreciation & 10 & 58.82 \\
& affect & 2 & 50.00 \\
& judgment & 0 & 0.00 \\
Existential & appreciation & 2 & 50.00 \\
& affect & 0 & 0.00 \\
& judgment & 1 & 100.00 \\
& appreciation & 0 & 0.00 \\
\hline
\end{tabular}

As Table 2 shows, judgment is the most common attitude overall, followed by appreciation and then affect. In relational clauses, judgment is also the most common attitude type, followed by appreciation and then affect. In mental clauses, it is appreciation, then judgment and affect, in that order. Meanwhile, in verbal clauses, affect and appreciation are equally frequent attitudes and there are no instances of judgment. In existential clauses, the data show only one instance of judgment.

\section{Material Clauses}

Material clauses are the most common clause type in the Greenpeace food campaigns. Clause 1-4 present examples of the material clauses that contain appraisals.

\section{Clause 1}

The current is our broken devastating planet.

food

system

Actor process: goal material

Clause 1, contains the material process devastating and indicates that there is a devastating action done by the current broken food system that has an impact on the goal, our planet. In other words, the clause represents the impact that an agent, namely, the current broken food system, has on Earth. Furthermore, the use of past progressive (is devastating) indicates that the impact 
is still in progress. Thus, the clause shows that the current broken food system is able to perform an action that Greenpeace appraises as negative against the broken food system, through the material process of devastation (i.e., negative capacity).

\section{Clause 2}

$\begin{array}{lllll}\text { Eco-farming } & \text { combines } & \begin{array}{l}\text { modern } \\ \text { science and } \\ \text { innovation }\end{array} & \begin{array}{l}\text { with } \\ \text { respect }\end{array} & \begin{array}{l}\text { for nature and } \\ \text { biodiversity. }\end{array} \\ \text { actor } & \text { target } & \begin{array}{l}\text { circum- } \\ \text { process: }\end{array} & \text { client } \\ \text { material } & & & \text { stance: } \\ & & & & \end{array}$

Clause 2 is a material clause that identifies the role of eco-farming. In the clause, eco-farming is the actor performing the action; combines is the material process followed by the target, modern science and innovation; with respect is the circumstance because this phrase comes along with the target; and nature and biodiversity is the client. The clause defines the action of eco-farming, namely, combining modern science and innovation. Since this process of combining science and innovation is done with respect for the environment in order to preserve nature and the diversity of living things, eco-farming maintains environmental sustainability. The process explains the action done by eco-farming as well as the method and objectives of the process, namely, with respect for nature and biodiversity as an action that emphasizes the importance of the environment. with respect for nature and biodiversity is an appraisal since the phrase states the function of ecofarming's method. The method contains a positive propriety that evaluates eco-farming positively. Subsequently, the item with respect for nature and biodiversity confirms that eco-farming is a positive appraised item because it fits with Greenpeace's vision and mission, such as preserving and protecting the environment.

\section{Clause 3}

Six corporations, Monsanto, control DuPont, Dow, Syngenta, Bayer, and BASF, actor

$$
\text { control }
$$

$$
\text { market pesticides. }
$$

process: goal

material 
Clause 4

Only four corporations, control ADM, Bunge, Cargill, and more than $75 \%$ of the global Dreyfus

actor

process: grain trade.

material

Clause 3 and 4, respectively, are material clauses with control as the verb. The actors in Clause 3 are Mosanto, DuPont, Dow, Syngenta, Bayer, and BASF, whereas the actors in Clause 4 are ADM, Bunge, Cargill, and Dreyfus. The target of the action in the form of a thing that is possessed by the enterprises is $75 \%$ of the world pesticides market in Clause 3 and more than $75 \%$ of the global grain trade in Clause 4. The actors have the same ability to dominate different goals, namely, controlling pesticides in Clause 3 and controlling the grain trade in Clause 4. The two material clauses, therefore, contain negative appraisals of Mosanto, DuPont, Dow, Syngenta, Bayer, BASF, ADM, Bunge, Cargill, and Dreyfus.

\section{Clause 5}

GMO crops

actor have gone

process:

material
Clause 5, is a material clause that contains a material process in the form of gone. The material process is modified by the auxiliary verb have, indicating the action has taken place. Meanwhile, the scope of the clause, mainstream, is a noun as a signifier that expresses conventional's activity. The material process gone is a process that creates changes, while the

$\begin{array}{ll}\text { only } & \text { in the past } 20 \\ \text { mainstream } & \text { years. } \\ \text { scope: process } & \text { circumstance: time }\end{array}$

time circumstance in the past 20 years indicates the state of the process. The actor is GMO crops (GMO: genetically modified organism) as an innovation aimed at producing crops in high quantities. Accordingly, the clause describes GMO crops as an entity that has become common in the last 20 years, but emphasizes that this is fairly recent. In other words, GMO 
crops are indicated to be mainstream which is an appraisal. Mainstream, therefore, is a judgment appraisal of positive normality for describing the state of GMO crops.

\section{Clause 6}

We

owner

$$
\text { literally }
$$

have

circumstance: process:

quality

relational

\section{Relational Clauses}

Clauses 6 to 15, respectively, are relational clauses that contain appraisals.
Clause 6 is a relational clause that consists of we, which refers to the readers and Greenpeace as the "owner" or possessor; literally, which is the circumstance of quality; have, which is a possessive relational process indicating ownership of something; and the power to change the world, which is an attribute of the relational process. The power is a noun that means a capability of a person to control things. In other words, the relational process brings a conclusion in the form of we, which is the owner of power.

In addition, the clause contains an appraisal in the attributes of the power to change the world, indicating that the power we own can be used to change the world. Therefore, the item is categorized as positive capacity.
Clause 7

It

advances
Clause 8

technologies

that

are

locally

available

and free or

inexpensive

for farmers.

actor

processes: goal

material conjunction

process:

attribute 
Clause 7 is a complex compound sentence that contains a material clause in the main clause. In the material clause, the pronoun it refers to eco-farming, followed by the verb advances as the material process that marks technologies as an action or deed. This clause indicates that the clause that are locally available and free or inexpensive for farmers, is the target of eco-farming. Meanwhile, Clause 8 is a relational clause in which the carrier refers to the main clause, namely, the technology of eco-farming, while are is a relational process that gives the characteristics of locally available and free or inexpensive for farmers as the carrier. The word available consists of verb avail and suffix -able which means able to used. This clause explains that eco-

\section{Clause 9}

It

carrier

$$
\text { is }
$$

process: relational farming technology is available locally and cheaply for farmers, such that eco-farming promotes technologies that provide benefits for farmers. The relationship of Clauses 7 and 8 shows a representation of ecofarming by the undertaken action in the form of advance and the applied attribute locally available and free or inexpensive for farmers. Therefore, the attribute applied in Clause 8 contains Greenpeace's appraisal of eco-farming in the form of locally available, which indicates that the technology can be gained for the farmers locally; thus, the appraisal has a positive capacity. Meanwhile, free or inexpensive for farmers is the appraisal item indicating the value of eco-farming technology; thus, the item has a positive valuation.
Clause 9 , is a relational clause that contains it referring to golden rice, which is given the attribute environmentally irresponsible by the relational process $i s$. the word irresponsible is an adjective that modifies golden rice as a noun. in other words, golden rice is identified as a thing that does not show responsibility. Environmentally is an adverb that modifies adjective; irresponsible. In addition, the adverb explains the impact of an irresponsible act to the environment. Thus, this attribute is an appraisal of golden rice, and since environmentally irresponsible is not in accordance with Greenpeace's value of protecting the environment, the appraisal item is a judgment of negative propriety. 
Clause 10

$\begin{array}{llll}\begin{array}{l}\text { Cattle } \\ \text { enterprises }\end{array} & \text { are } & \text { responsible } & \text { for up to 80\% of } \\ \text { carrier } & \text { process: } & \text { attribute } & \begin{array}{l}\text { Amazon deforestation } \\ \text { circumstance: reason }\end{array} \\ & \text { relational } & & \end{array}$

Clause 10, is a relational clause with are as the verb that explains responsible as the adjective attribute, and for up to $80 \%$ of Amazon deforestation as the circumstance. The carrier cattle enterprises are considered to have responsibilities concerning the

\section{Clause 11}

Industrial

is

agriculture

Carrier process:

material
Amazon rainforest. Hence, there is an appraisal toward the carrier in referring to the attribute responsible, namely, positive propriety because it defines the obligation of cattle enterprises for the environment.
Clause 11, is a relational clause with the relational process is as a marker, industrial agriculture as the carrier, and a system with an expiration date as the attribute. the phrase a system with an expiration date is a noun phrase which is a complement of industrial agriculture. A system with an expiration date is a characteristic of industrial agriculture. In other words, the agriculture industry has a limit in food management. This characteristic of industrial agriculture contains a value appraisal, namely, a negative valuation as the evaluation of the nature of the agricultural industry.

\section{Clause 12}

Using GE crops to try to solve is problems of malnutrition

\section{is}


Clause 12, is a relational clause with is as the realization of the relational process to connect using GE crops to try to solve the problem of malnutrition to the attribute simply the wrong approach and a risky distraction. Using GE seeds, therefore, is not the solution to overcome malnutrition, because GE is considered dangerous. This characterization of the attribute toward the carrier is an appraisal. The words wrong and risky are inscribed appraisal since wrong means not correct action and the latter is the possibility of environmental danger. In other words, the attribute simply wrong approach and risky distraction is the Greenpeace evaluation of GE crops as an incorrect step of using GE crops, which is an appreciation of negative valuation. On the other hands, risky is a negative capacity because it defines the dangerous possibility to the environment by using GE crops.

Clause 13

$\begin{array}{lll}\text { Livestock } & \text { is } & \begin{array}{l}\text { the most significant contributor to nitrogen and } \\ \text { phosphorus pollution of streams, rivers, and } \\ \text { coastal waters. }\end{array} \\ \text { carrier } & \begin{array}{l}\text { process: } \\ \text { relational }\end{array} & \text { Attribute }\end{array}$

In Clause 13, is constitutes a relational process that identifies livestock as the most significant contributor of to nitrogen and phosphorus pollution of streams, rivers, and coastal waters. The clause thus describes that livestock contributes to river pollution. The word significant is an adjective which identifies livestock as sufficiently great causal of pollution. Accordingly, the most significant contributors to nitrogen and phosphorus pollution of streams, rivers, and coastal waters have the attribute of a negative valuation appraisal since there is an evaluation of the livestock characteristics, namely, that they adversely affect the environment.

\section{Clause 14}

$\begin{array}{lll}\text { Food } & \text { is } & \text { happiness. } \\ \text { carrier } & \text { process: relational } & \text { attribute }\end{array}$

Clause 14, is an attributive relational relational process characterizes food by the clause with is as the relational process. The use of happiness. Happiness is an inscribed 
appraisal because it depicts the emotion of the state of being happy. Therefore, it is a positive feeling. In other words, happiness

\section{Clause 15}

It

carrier ensures

process:

relational is an attribute of food, and it contains an appraisal of the affect of happiness.
Clause 15, is a paratactic clause from the previous clause, Eco-farming combines modern science and innovation with respect for nature and biodiversity, where the pronoun it refers to eco-farming. The clause is a relational clause in which ensures is the attributive relational process that confirms that the attribute healthy farming and healthy food is associated with ecofarming. In other words, eco-farming can produce healthy farming and healthy food because there is certainty realized from the relational process. Therefore, ensure is a verb that defines the act of making safe which characterizes the eco-farming as a safe method to the environment. Hence, ensure is an appraisal item which is included to affect security.

\section{Mental Clauses}

Mental clauses in the food campaigns refer to entities perceived in different ways by Greenpeace, as follows.

\section{Clause 16}

Grown chemically, pumped with additives, does with the preservatives and flavor enhancers, and synthetically manufactured farmed food not healthier taste- alternative phenomenon tally reality. process: circumstance: mental comitative 
Clause 16, includes the mental process of perception taste-tally involving the human senses. Meanwhile, the phenomenon indicates that food that exists today is grown chemically, pumped with additives, preservatives and flavor enhancers, and synthetically manufactured farmed. The negation in the process does not indicate that the phenomenon is not in line with expectations. The circumstance in the clause offers a comparison of the idea of processed food with the reality that this food is not healthy. The role of the senser is not filled in the clause, but Greenpeace, as the carrier of the campaign, could, therefore, be called the senser. The clause contains an appreciation, namely, a negative reaction that can be explained by the presence of a mental process, mainly the perception of artificial food, which is not compatible with reality. Meanwhile, grown chemically, pumped with additives, preservatives, and flavor enhancers and manufactured and synthetically farmed food are phrases that contain an appraisal of negative composition. In this case, Greenpeace articulates that artificial food is not good food.

\section{Verbal Clause}

Clause 17 is a verbal clause that contains an appraisal.

\section{Clause 17}

$\begin{array}{lll}\text { Say } & \text { "No" } & \text { to industrial agriculture } \\ \text { process: verbal } & \text { verbiage } & \text { target }\end{array}$

It is an imperative clause, which means it issues a command. Say is the verbal process, no is verbiage, and industrial agriculture is the target. The subject or sayer is the reader, although this is not expressed overtly. There is an appraisal in the verbiage no, which indicates that products and techniques developed by the agricultural industry should be avoided. Thus, the appraisal item falls within the negative propriety domain.

\section{Existential Clause}

An existential clause in the Greenpeace food campaigns identifies the existence of an entity.

\section{Clause 18}

$\begin{array}{lll}\text { There } & \text { is } & \text { a better system. } \\ \text { subject } & \text { process: existential } & \text { existent }\end{array}$


In Clause 18, is is the existential process indicating that the entity (system) exists at present. The clause has a parataxis connection with The fact that the current broken food system is devastating our planet. In other words, the existential clause means that apart from the current, damaged food system, there is a better food system. The clause then becomes an opening to a new narrative on this better alternative food system. Thus, the existential clause contains an appraisal indicating that there is a better food system for the environment, such that the appraisal item has a positive capacity judgment.

\section{Summary on Clause Types}

The results of the quantitative and qualitative analysis show that judgment is the most common form of appraisal in the campaign, especially in material clauses. Judgment as the valuation indicates that the actor performs actions that cause change or have impacts on the environment. The appraisal judgment items are capacities that emphasize the ability to do something, propriety that identifies actions that should be done, and normality indicating the prevalent conditions. Meanwhile, judgment in the relational clauses indicates the character of the item's appraised behavior, while judgment in the mental clauses describes the evaluation of what Greenpeace perceives as being for or against the food system.

In the appraisal system, appreciation is found the most in relational clauses, which contain evaluations as characteristics or identity in the food campaigns. Meanwhile, in the material clauses, appreciation appears in relation to phenomena that are considered changes or actions by an actor. In the mental clauses, appreciation shows Greenpeace's judgment or evaluation concerning the food system, while in the verbal clauses it signifies the things uttered in the Greenpeace food campaigns.

In this data, the negative forms refer to industrial agriculture, genetic engineering for crops, and livestock, which are characterized as having the capability of yielding harmful effects on the environment, performing actions that have consequences for the environment, and being out of line with the principles of Greenpeace, such as maintaining and preserving the environment. Greenpeace evaluated entities such as large enterprises as contributors to environmental damage.

Meanwhile, the positive forms refer to eco-farming, a type of farming that is done ecologically and takes into account innovation and respect for the environment. Thus, Greenpeace judges that innovations in food systems such as industrial agriculture, livestock, and genetically modified crops are destroyers of the environment, while it considers eco-farming a system that respects the environment and is, therefore, the right approach.

\section{Graduation in Greenpeace Food Campaigns}

Graduation is an appraisal subsystem that analyzes the high and low intensity of the appraisal. That is, it may be used to reinforce or weaken an evaluation. Below 
is an analysis of graduation items in the Greenpeace food campaigns.

Force: Quantification. The data contain various examples of quantification.

(1) 365-day supermarket availability

(2) crams hundreds of animals

(3) generates as much as

In (1), the quantification of supermarket availability is strengthened because the scale is a number (365-day) that refers to the frequency of the entity. In (2), hundreds is a number that quantifies the noun. Then, in (3), as much as is a graduation that modifies the verb, which is a form of number quantification included in upscaling.

(4) can feed the world for generations

In (4), the graduation is a proximitytime quantification (upscaling). The phrase for generations as time proximity reinforces the idea of a long-term effect. Therefore, the quantification on food's campaign vividly describes the extent of effect the entity to the environment. The numbers that have been mentioned make the evaluation stronger.

Force: Qntensification. Examples (5) to (8) demonstrate force, or intensification, in the text of the food campaigns.

(5) mean more and more

(6) more meat aware

(7) the more we can do to change it

(8) eating less meat
More and more in (5) is a form of repetition, which is the intensification mode. More is used to modify the verb mean. Since the word more shows a degree of comparison (i.e., something is more than the other), the degree is upscale. Meanwhile, more in (6) is an intensification that reinforces the adjective meat aware. Then, the comparative in (7) the more we can do to change it contains a quality intensification that reinforces the verb. The phrase less meat in (8) is a form of graduation involving reduced quantification of the noun.

(9) grown chemically

(10) simultaneously tackling

(11) locally available

(12) especially vulnerable

The graduation items in (9) to (12) are intensifications whose scale are increasing, meaning they confirm the appraisal. In (9) and (10), respectively, chemically and simultaneously modify verbs, while in (11) and (12), locally and especially modify adjectives by adding attitudinal tone. In addition, especially in (12) is a maximization, which assigns the highest possible intensity to reinforce the appraisal of importance.

\section{(13) the most effective \\ (14) precious water supply}

In (13), the most is a superlative, so the phrases have a rising intensification. Then, in (14), precious is an intensification of quality with upscaling. It modifies the noun 
water supply by adding an attitudinal tone.

The intensification in the food campaign have shown that Greenpeace emphasizes on the quality. In other words, Greenpeace wants to influence the readers by using intensity degree which makes the readers understand the quality of appraised items.

Focus. In addition to force, instances of focus are found, such as in (15) and (16).

(15) We literally have the power to change the world.

(16) the real long-lasting solution populations affected by Vitamin A Deficiency need

In (15), literally describes the power of the readers and Greenpeace to have an impact on the food system. In (16), real is used to point to eco-farming as a solution to cure Vitamin A deficiency (VAD). Both examples use sharpening to emphasize an entity's impact on the environment, whether it is good or bad. Moreover, these instances of sharpening clarify Greenpeace's intention to protect the environment.

Thus, the graduations found in the Greenpeace food campaigns are intensifications concerning the degree of the intensity evaluation and sharpening. The graduations modify the verbs, nouns, and adjectives that emphasize evaluations. Upscaling or rising scale serves to demonstrate a strong position in order to align Greenpeace's evaluation with readers. Meanwhile, the downscale found in the data provides an opportunity for readers to examine the position of the Greenpeace campaigns and instances of sharpening make the campaign more convincing.

\section{CONCLUSION}

This study discusses the attitude appraisal contained in the clauses identified by transitivity in the text of Greenpeace food campaigns. The results show that material clauses have the most appraisals related to impacts or changes to the environment caused by actors. Meanwhile, relational clauses identify the characteristics of the Greenpeace food campaign. For example, the appraisal of effect reveals Greenpeace's feelings about the environment. Moreover, judgment, particularly capacity, is the most frequent appraisal, as indicated by the modal can and processes in the clauses such as control, have, and make. Capacity in the clauses depicts that an entity's characteristic or action has an impact on the environment.

On the other hand, graduation in Greenpeace's food campaigns is mostly upscaling that intensifies attitudes. This graduation is primarily achieved through lexical forms such as comparative and superlative degrees. In particular, Greenpeace uses sharpening to convince readers of the food system's impact on the environment. Hence, Greenpeace makes evaluations by appraising the impacts that an entity has on the environment with rising attitudinal tone.

Thus, Greenpeace's attitudes in assessing various entities in its food campaigns manifest through affect and appreciation judgment. Entities that 
are appraised positively include ecofarming, the campaign, food, humans, and Greenpeace. These entities are seen as positive because their actions have a positive impact on the environment in accordance with Greenpeace's vision and mission. On the other hand, entities that are appraised negatively include industrial agriculture, livestock, GE, pesticides, and large enterprises, as they can damage or threaten the environment. Since some innovations aimed at improving food productivity have yielded negative effects, Greenpeace emphasizes the real or potential harm they could inflict on the environment.

This study has potential limitation of which is not including another subappraisal; engagement. Since most of the source the evaluation is from Greenpeace's site therefore we suggest the next researcher to find out all aspects of appraisal in another ecology discourse.

\section{ACKNOWLEDGMENTS}

We gratefully acknowledge financial support from DPRM UI through PITTA (Publikasi Terindeks Internasional untuk Tugas Akhir Mahasiswa) grant of the year 2018. We would also like to thank Enago (www.enago. com) for the English language review.

\section{REFERENCES}

Bednarek, M. (2008). Emotion talk across corpora. New York, USA: Palgrave Macmillan. doi: $10.1057 / 9780230285712$

Bednarek, M., \& Caple, H. (2010). Playing with environmental stories in the news: Good or bad practice? Discourse \& Communication, 4(1), 5-31. doi: 10.1177/1750481309351206

Cheng, W. (2012). Exploring corpus linguistics. New York, USA: Routledge.

Halliday, M., \& Matthiessen, C. (2014). An introduction to functional grammar. London, England: Arnold.

Haratyan, F. (2011). Halliday's SFL and social meaning. In 2nd International Conference on the Humanities, and Social Sciences Historical. IPEDR, 7, 260-264.

Hopper, P. J., \& Thompson, S. A. (1980). Transitivity in grammar and discourse. Language, 56(2), 251-299.

Hunston, S., \& Thompson, G. (2000). Evaluation: An introduction. In S. Hunston, G. Thompson (Eds.), Evaluation in text: Authorial stance and the construction of discourse (pp. 1-26). New York, USA: Oxford University Press.

Martin, J., \& White, P. (2005). The language of evaluation: Appraisal in English. New York, USA: Palgrave.

Mayo, M. A., \& Taboada, M. (2017). Evaluation in political discourse addressed to women: Appraisal analysis of Cosmopolitan's online coverage of the 2014 US midterm elections. Discourse, Context \& Media, 18, 40-48.

Nurdiyani, N. (2019). Bentuk-bentuk kekhawatiran pegiat lingkungan hidup dalam berita online atas rencana kepindahan Ibukota ke Kalimantan (Kajian apraisal dalam linguistik sistemik fungsional) [The concerns of enviromentalists in online news towards the movement of The Capital City to Kalimantan (Study of appraisal in functional systemic linguistics)]. In Prosiding Seminar Nasional Linguistik dan Sastra (SEMANTIKS), 427-435. 
O’Donnell, M. (2014). Exploring identity through appraisal analysis: A corpus annotation methodology. Linguistics and the Human Sciences, 95-116.

Oteíza, T. (2017). The appraisal framework and discourse analysis. In T. Bartlett, G. O'Grady (Eds.), The Routledge handbook of systemic functional linguistics (pp. 481-496). London, England: Routledge.

Read, J., \& Carroll, J. (2012). Annotating expressions of appraisal in English. Journal of Language Resources and Evaluation, 421-447. doi: https:// doi.org/10.1007/s10579-010-9135-7

Santoso, A. (2008). Halliday trail in critical linguistics and critical discourse analysis. Jurnal Bahasa dan Seni, 36(1), 1-15.

Scherrer, Y. M. (2009). Environmental conservation NGOs and the concept of sustainable development. Journal of Business Ethics, 85(3), 555. doi: 10.1007/s10551-009-0211-0
Stibbe, A. (2010). Ecolinguistics: Language, ecology and the stories we live by. New York, USA: Routledge.

Trampe, W. (2001). Language and ecological crisis: Extracts from a dictionary of industrial agriculture. In A. Fill \& P. Mühlhäusler (Eds.), The Ecolinguistics Reader, Language, Ecology and Environment (pp. 232-240). London, England: Continuum.

White, P. R. R. (2015). Appraisal theory. In Tracy, K., Illie, C., \& T. Sandel (Eds.), The International Encyclopedia of Language and Social Interaction (pp. 1-7). Oxford, England: Wiley Blackwell.

Yuniawan, T., Rokhman, F., Rustono, Mardikantoro, H. B., Zulaeha, I., Yuwono, U., Prayitno, H. J., \& Rohmadi, M. (2019). The function of ecolexicons in conservation news texts published in mass media. International Journal of Innovation, Creativity and Change, 7(11), 301-313. 